\title{
Aktivitas Antibakteri Ekstrak Jeruju Acanthus ilicifolius terhadap Bakteri Multi Drug Resistant
}

\section{Delianis Pringgenies, Wilis Ari Setyati, Dwicahyo Setiyo Wibowo dan Ali Djunaedi}

\author{
Departemen IImu Kelautan, Fakultas Perikanan dan Ilmu Kelautan, Universitas Diponegoro \\ Jl. Prof. H. Soedarto, S.H., Tembalang, Semarang, Jawa Tengah, 50275 Indonesia \\ Email: pringgenies@yahoo.com
}

\section{Abstract \\ Antibacterial Activity of Acanthus ilicifolius Extract against Multi Drug Resistant Bacteria}

This study aims to determine the antibacterial activity of the Jeruju fraction extract (roots, stems and leaves) against Multi Drug Resistant (MDR) bacteria. Extraction uses the solid-liquid extraction method. Fractionation was done by Thin Layer Chromatography (TLC) and Open Column Chromatography (OCC). The antibacterial activity was tested by the diffusion method for different concentrations. The test bacteria were MDR bacteria: Klebsiella sp, Coagulant negative stapylococi (CNS), Enterobacter 5, Enterobacter 10, E. Coli and Pseudomonas sp. The activity test results showed the crude extract of the root with ethyl acetate solvent had the highest antibacterial activity. The results of the Open Column Chromatography activity test showed that the fraction I, II and III of the root extracts had antibacterial activity against the test bacteria. Fraction I was active against Enterobacter 5 with inhibition zones of $10.0 \pm 0.34 \mathrm{~mm}$. Fraction II was active against Coagulant negative stapylococi with inhibition zone diameters of $11.80 \pm 0.16 \mathrm{~mm}$. Fraction III has the highest antibacterial activity against Enterobacter 10, Klebsiella sp, Pseudomonas sp. danE. Coli successively produce inhibition zones (13.98mm \pm 0.58$)$, (13.22mm \pm $0.50)$, $(13.15 \mathrm{~mm} \pm 1.15)$ and $(13.10 \mathrm{~mm} \pm 0.04)$ and the highest in and Results the study concluded that root extracts had the highest antibacterial bioactivity compounds compared to stem and leaf extract samples. Furthermore, the MDR antibacterial activity test showed that the sample III fraction had the best inhibitory zone on the best bacteria as an anti-bacterial MDR: Klebsiella sp, Enterobacter 10, E. Coli and Pseudomonas sp

Keywords: Acanthus ilicifolius; antibacterial; MDR; inhibition zone

\begin{abstract}
Abstrak
Penelitian ini bertujuan mengetahui aktivitas antibakteri fraksi ekstrak Jeruju, (akar, batang dan daun) terhadap bakteri Multi Drug Resistant (MDR). Ekstraksi menggunakan metode ekstraksi padat-cair. Fraksinasi dilakukan dengan Kromatografi Lapis Tipis (KLT) dan Kromatografi Kolom Terbuka (KKT). Uji aktivitas antibakteri dengan metode difusi agar konsentrasi yang berbeda. Bakteri uji adalah bakteri MDR: Klebsiella sp, Coagulant negative stapylococi (CNS), Enterobacter 5, Enterobacter 10, E. Coli dan Pseudomonas sp. Hasil uji aktifitas antibakteri menunjukan ekstrak kasar akar dengan pelarut etil asetat memiliki aktifitas antibakteri tertinggi pada semua bakteri uji. Hasil uji aktivitas fraksi Kromatografi Kolom Terbuka memperlihatkan fraksi I, II dan III ekstrak akar memiliki aktivitas antibakteri terhadap bakteri uji. Fraksi I aktif terhadap Enterobacter 5 dengan zona hambat 10,0 $\pm 0,34 \mathrm{~mm}$. Fraksi II aktif terhadap Coagulant negative stapylococi dengan diameter zona hambat $11,80 \pm 0,16 \mathrm{~mm}$. Fraksi III memiliki aktivitas antibakteri yang paling tinggi terhadap Enterobacter 10, Klebsiella sp, Pseudomonas sp. dan E. Coli. berturut - turut menghasilkan zona hambat $(13,98 \mathrm{~mm} \pm 0,58)$, $(13,22 \mathrm{~mm} \pm 0,50)$, $(13,15 \mathrm{~mm} \pm 1,15)$ dan $(13,10 \mathrm{~mm} \pm 0,04)$ serta tertinggi pada dan Hasil penelitian disimpulkan bahwa ekstrak akar memiliki senyawa bioaktifitas antibakteri
\end{abstract}


tertinggi dibandingkan sampel ekstrak batang dan daun. Selanjutnya uji aktifitas antibakteri MDR memperlihatkan bahwa sampel fraksi III memiliki zona hambat terbaik pada bakteri terbaik sebagai anti bakteri MDR: Klebsiella sp, Enterobacter 10, E. Coli dan Pseudomonas sp.

Kata Kunci : Acanthus ilicifolius; antibakteri; MDR; zona hambat

\section{PENDAHULUAN}

Mangrove Jeruju Acanthus ilicifolius merupakan tanaman yang berbeda bentuknya dibandingkan dengan jenis mangrove lainnya, yaitu pada batang, cabang dan rantingnya dikelilingi oleh duri halus dan tajam serta memiliki bunga serta merupakan salah satu jenis mangrove yang berasosiasi dengan tumbuhan liar. Biasanya tumbuhan ini hidup pada atau dekat mangrove, sangat jarang di daratan. Memiliki kekhasan sebagai herba yang tumbuh rendah dan kuat, yang mempunyai kemampuan secara vegetative karena perakarannya yang berasal dari batang horizontal, sehingga membentuk bagian yang besar dan kukuh. Bunga kemungkinan diserbuki aleh serangga dan burung. Biji tertiup angin, sampai sejauh 2 meter (Noor, dkk.1999). Jeruju diketahui selain sebagai bahan pangan juga berpotensi mengandung senyawa bioaktif. Hal ini dikarenakan beberapa senyawa metabolit baru-baru ini dengan struktur kimia dan tergolong salah satu diversitas dari 'kelaskelas kimia' telah dikarakterisasi dari tumbuhan mangrove dan tumbuhan asosiasinya. Dari beberapa senyawa metabolit dihasilkan berbagai senyawa bioaktif yang berpotensi sebagai senyawa antibakteri. Pada A. ilicifolius menghasilkan senyawa bioaktif steroid, saponin, flavonoid dan tannin. Menurut Manilal et al. (2009) A. ilicifolius secara in vitro bersifat vibriosidal yang aktif melawan tiga spesies vibrio, yaitu $\checkmark$. alcaligenes $(8 \mathrm{~mm}), V$. vulnificus $(9 \mathrm{~mm})$, dan $V$. alginolyticus $(10 \mathrm{~mm})$. Perbedaan aktivitas antimikroba antar mangrove dapat dikarenakan adanya perbedaan substansi antimikroba yang ada.

Senyawa antibakteri sebagai salah satu bahan antimikroba memiliki 3 macam bentuk kerja, yaitu bakteriostatik, bakterisidal dan bakterilitik. Mekanisme bakteriostatik adalah menghambat sintesis protein dengan mengikat ribosom, sedangkan bakterisidal mencegah pertumbuhan dan menyebabkan kematian, namun tidak menyebabkan sel bakteri menjadi lisis. Berbeda dengan bakterisidal, bakterilitik bekerja dengan cara membuat lisis sel-sel bakteri. Proses lisisnya sel bakteri dapat terlihat dari penurunan jumlah sel ataupun kekeruhan setelah bahan tersebut ditambahkan (Brock dan Madigan, 1991). Sedangkan menurut Siegel et al., (2007) bahwa MDR (Multi-drug Resistant) adalah mikroorganisme, umumnya bakteri yang telah resisten terhadap lebih dari satu kelas senyawa antimikroba. Bahaya resistensi antibiotik dapat semakin meningkat sebagai akibat dari pemilihan usaha pengendalian bakteri oleh antibiotik yang digabungkan dengan kemampuan bakteri dalam memilih penyebaran dan kemampuan timbulnya resistensi (Filius et al., 2005). Berdasarkan hal tersebut, maka tujuan penelitian adalah untuk mengetahui aktifitas antibakteri dari fraksi ekstrak akar, batang dan daun dari tanaman A. ilicifolius terhadap bakteri MDR (multidrug resistent).

\section{MATERI DAN METODE}

Materi yang digunakan dalam penelitian ini adalah daun, batang, akar dari tumbuhan Jeruju A. ilicifolius. Materi uji aktifitas antibakteri adalah bakteri MDR meliputi bakteri: Klebsiella sp, Coagulant negative stapylococi (CNS), Enterobacter 5, Enterobacter 10, E. Coli dan Pseudomonas sp. Pengambilan sampel $A$. ilicifolius dilakukan dengan metode sampling purposive atau berdasarkan atas adanya tujuan tertentu bukan berdasarkan tempat, random, daerah. Sampel diperoleh dari komunitas mangrove di pantai Teluk Awur Jepara profinsi Jawa Tengah. Sampel Jeruju setelah dibersihkan dari kotoran lumpur kemudian dipisahkan antara daun, batang, dan akar. Selanjutnya dipotong kecil-kecil kurang lebih $2 \times 2 \mathrm{~cm}$. Sehingga didapat 500 gram daun basah, 500 gram batang 
basah,dan 500 gram akar basah. Sampel kemudian dijemur menggunakan sinar matahari secara tidak langsung. Sampel kering Jeruju A. ilicifolius yang dihasilkan adalah 300 gram daun kering, 270 gram batang kering, dan 155 gram akar kering.

Sampel Jeruju kering direndam dengan pelarut $\mathrm{n}$-heksan hingga terendam seluruhnya selama $1 \times 24$ jam. Setelah 24 jam, rendaman disaring sedangkan ampas dipisahkan. Ampas kembali direndam dengan pelarut $\mathrm{n}$-heksan selama 2 jam. Perendaman diulang hingga tidak terjadi perubahan warna atau menjadi jernih. Metode ekstraksi yang digunakan dalam penelitian ini adalah metode ekstraksi padatcair (solid-liquid) dengan menggunakan rotavapour sebagai alat untuk melakukan ekstraksi (Pavia et al., 1995). Setelah itu disaring dengan kertas saring. sedangkan filtratnya dievaporasi dengan rotavapour pada suhu $45^{\circ} \mathrm{C}$. Ekstrak dipindahkan dari erlenmeyer flask kedalam botol vial, kemudian dikeringkan lagi dengan rotavapour (Burgess et al., 2003). Selanjutnya ampas direndam kembali dengan etil asetat dan metanol secara berurutan dengan cara yang sama seperti perlakuan pada pelarut $n$ heksan.

Media yang digunakan dalam penelitian ini adalah media Nutrien Agar dan Nurtien Broth. Media Nutrien Agar dalam penelitian digunakan untuk membuat agar miring dalam fresh culture dan penyimpanan isolat. Selain itu juga digunakan sebagai media uji sensitivitas antibakteri. Media Nutrien Agar dibuat dengan cara mencampurkan 2,2 gram NA dan aquades sebanyak $100 \mathrm{~mL}$ sedangkan media Nurtien Broth digunakan sebagai media kultur bakteri uji.Media Nutrien Broth dibuat dengan cara mencampurkan 0,25 gram pepton, 0,05 gram yeast, dan aquades sebanyak $100 \mathrm{~mL}$. Masing-masing larutan media tersebut dihomogenkan menggunakan stirrer hot plate sambil diaduk hingga mendidih. Larutan kemudian disterilkan dalam autoclave pada suhu $121{ }^{\circ} \mathrm{C}$ dan tekanan 1 atm selama 15 menit. Setelah dikeluarkan dari autoclave, Nutrien Agar dituangkan ke dalam cawan petri dan didiamkan hingga memadat, sedangkan Larutan Nutrien Broth dituang ke dalam tabung reaksi.
Uji kontrol positif dilakukan dengan menggunakan antibiotik Streptomisin yang diujikan terhadap bakteri uji dengan konsentrasi $80 \mathrm{\mu g} /$ disk. Hal ini bertujuan untuk mengetahui adanya diameter zona hambatan yang terbentuk oleh antibiotik Streptomisin. Antibiotik kemudian diteteskan diatas kertas cakram pada media agar yang telah ditanami bakteri uji. Pengamatan zona hambatan dilakukan setelah inkubasi selama 24 jam, ukur diameter zona hambat yang terbentuk. Uji kontrol negatif dilakukan dengan menggunakan ketiga pelarut yakni; n-hexane, etil asetat, dan metanol terhadap bakteri uji. Uji ini dilakukan untuk mengetahui ada atau tidaknya pengaruh pelarut dalam pembentukan diameter zona hambatan.

Uji aktivitas antibakteri ekstrak Jeruju terhadap bakteri uji dilakukan dengan menggunakan 0,1 gram ekstrak kasar. Kemudian ekstrak kasar sebanyak 0,1 gram diencerkan untuk dibuat larutan stok dengan konsentrasi $80 \mu \mathrm{g} / \mu \mathrm{l}$. Pasang paperdisk pada media uji. Hasil pengenceran dengan konsentrasi $5 \mu \mathrm{g} /$ disk, $10 \mu \mathrm{g} /$ disk, $20 \mu \mathrm{g} /$ disk, $40 \mu \mathrm{g} /$ disk, dan $80 \mu \mathrm{g} /$ disk diteteskan dengan mikropipet sebanyak $10 \mu \mathrm{g} / \mu \mathrm{l}$ pada paperdisk. Kemudian media uji disimpan dalam inkubator pada suhu $37^{\circ} \mathrm{C}$ selama 24 jam. Setelah 24 jam median diamati dan diukur diameter zona hambatnya dengan menggunakan jangka sorong. Zona hambat yang terbentuk berupa zona bening yang terbentuk disekitar paperdisk atau zona yang tidak ditumbuhi bakteri.

Analisis KLT dilakukan dengan menggunakan fasa diam berupa silika gel dan fasa gerak berupa etil asetat,atau campuran etil asetat dengan metanol, atau campuran etil asetat dengan n-hexane dalam berbagai perbandingan. KLT dilakukan dengan tujuan mencari pelarut yang cocok untuk memisahkan senyawa dalam ekstrak (Kristanti dkk, 2008). KLT dilakukan dengan Plat dipotong-potong dengan ukuran panjang $5 \mathrm{~cm}$ dan lebar 1 $\mathrm{cm}$ (Gandjar dan Rohman, 2007). Pada salah satu ujung dibuat garis-garis dengan jarak 0,5 $\mathrm{cm}$ sebagai titik awal sedangkan, pada ujung yang lain dibuat garis sebagai titik akhir. Ekstrak sampel ditotolkan pada pelat KLT dengan menggunakan pipet kapiler. 
Setelah itu pelat dimasukkan kedalam gelas beaker yang berisi fase gerak, tetapi spot jangan sampai terendam dalam elven, kemudian gelas beaker ditutup rapat sampai elven mencapai titik akhir. Pelat diangkat dan dikeringkan. Noda atau spot yang terbentuk dilihat menggunakan sinar UV (Stahl, 1985). Diamatai noda yang terbentuk dan dicatat nilai Rf nya. Proses diatas diulangi dengan variasi perbandingan volume eluen yang berbeda sehingga Rf yang dihasilkan memiliki variasi yang banyak.

Kromatografi Kolom Terbuka bertujuan untuk memisahkan (fraksinasi) komponenkomponen ekstrak berdasarkan kepolarannya. Fraksinasi ekstrak dari masing-masing bagian mangrove dilakukan dengan prosedur menurut Harborne (1987) menggunakan kromatografi lapis tipis silika gel dan kolom kromatografi (Subagiyo et al., 2005). Elven yang digunakan adalah campuran etil asetat dan n-heksan (2: 1). Rendam silika gel $\mathrm{G}_{60}$ (adsorben) sebanyak $25 \mathrm{~g}$ kedalam gelas beker berisi elven sampai semua terendam, diaduk sampai homogen dan dibiarkan selama 2 jam.

Kolom terlebih dahulu dikeringkan sebelum digunakan, kemudian kapas dimasukkan kedalam dasar kolom hingga rata dan padat, kemudian letakkan kertas saring diatasnya. Adsorben dimasukkan ke dalam kolom secara perlahan-lahan sehingga adsorben benar-benar mampat dan lapisan adsorben rata tidak terdapat gelembung udara. Tutup rapat bagian atas kolom dengan alumunium foil. Kemudian biarkan selama 24 jam hingga adsorben memadat. Adsorben dijaga agar tetap terendam elven.

Ekstrak etil asetat sebanyak 1 gram dimasukkan ke dalam gelas beker, beri sedikit pelarut, kemudian tambahkan sedikit demi sedikit adsorben sebanyak $5 \mathrm{~g}$. Setelah adsorben memadat, letakkan kertas saring pada bagian atas adsorben. Kemudian isi kolom dengan ekstrak, usahakan agar tetap terendam eluen. Elusi ekstrak dengan menambahkan elven dengan kecepatan 1 tetes/detik. Kran di bagian bawah kolom dibuka agar pelarut dapat keluar secara perlahan, kecepatan aliran sama dengan kecepatan penambahan elven. Eluat ditampung dalam vial masing-masing sebanyak $15-20 \mathrm{ml}$. Fraksinasi dihentikan jika eluat yang ditampung sudah tidak berwarna. Tiap vial dianalisis dengan KLT. Vial yang menunjukkan pola spot yang sama lalu dikelompokkan dalam satu fraksi kemudian pelarutnya divapkan menggunakan rotavapour.

Uji antibakteri dilakukan dengan metode difusi agar atau metode cakram (agar disc-diffusion method) menurut prinsip Kirby-Baver. Prinsip dari metode ini adalah penghambatan pertumbuhan mikroorganisme yang diketahui dari daerah sekitar paper disk yang tidak ditumbuhi oleh mikroorganisme. Pengulangan dilakukan sebanyak 3 (tiga) kali. Adanya aktivitas antibakteri ditunjukkan oleh terbentuknya zona penghambatan pertumbuhan mikroorganisme disekitar cakram (Volk dan Wheeler,1990). Kemudian diameter zona hambat diukur tiap 24 jam, selama $3 \times 24$ jam dengan menggunakan jangka sorong.

\section{HASIL DAN PEMBAHASAN}

Hasil ekstraksi sampel Jeruju daun memperlihatkan hasil ekstraksi berwarna hijau kehitaman. Hasil ekstraksi daun menunjukan pelarut metanol lebih banyak menghasilkan ekstrak, yaitu 12.46 gram, sedangkan yang paling sedikit dihasilkan dengan 5.92 gram adalah dari pelarut n-heksan. Hasil ekstraksi batang menunjukan pelarut metanol lebih banyak menghasilkan ekstrak, yaitu 10.89 gram, sedangkan yang paling sedikit dihasilkan dengan 3.58 gram adalah dari pelarut n-heksan. Hasil ekstraksi akar menunjukan pelarut metanol lebih banyak menghasilkan ekstrak, yaitu 6.76 gram, sedangkan yang paling sedikit dihasilkan dengan 1.73 gram adalah dari pelarut etil asetat. Uji kontrol positif dilakukan untuk mengetahui kebenaran adanya diameter zona hambatan yang terbentuk oleh antibiotik komersial. Pada uji kontrol positif ini antibiotik yang digunakan adalah amoxicillin dan streptomycin.

Hasil uji amoxicillin terhadap bakteri uji menunjukan tidak adanya zona hambat terhadap bakteri uji, sedangkan pada uji streptomisin menunjukan adanya zona 
hambat terhadap bakteri uji. Aktivitas streptomisin paling tinggi adalah pada bakteri Pseudomonas sp, sedangkan aktivitas Streptomisin terendah adalah terhadap bakteri CNS.

Uji kontrol negatif dilakukan untuk mengetahui pengaruh dari pelarut $n$-hexane, etil asetat, dan metanol dalam pembentukan zona hambatan terhadap bakteri uji. Apabila kontrol negatif mengalami pembentukan diameter zona hambatan maka hasil pengukuran diameter zona hambatan pada perlakuan dikurangi dengan diameter zona hambatan dari pelarut tersebut.

Hasil uji pelarut menunjukkan bahwa uji pengaruh pelarut $n$-hexane, etil asetat, dan metanol terhadap bakteri uji yaitu bakteri Klebsiella, Escherichia coli, Pseudomonas sp, CNS, Entero5, 10 tidak menunjukkan adanya aktivitas antibakteri. Uji kualitatif aktivitas antibakteri ekstrak Acanthus ilicifolius dilakukan dengan menggunakan ekstrak kasar sebanyak 0,1 gram yang diujikan terhadap bakteri uji yaitu bakteri bakteri Klebsiella, Escherichia coli, Pseudomonas sp, CNS, Entero5, Entero 10.

Hasil uji aktivitas menunjukkan bahwa ekstrak kasar daun, batang, dan akar Acanthus ilicifolius dengan pelarut n-heksan tidak menunjukkan aktivitas antibakteri pada semua jenis bakteri uji. Aktivitas antibakteri dapat terlihat pada ekstrak akar kasar Acanthus ilicifolius dengan pelarut etil asetat untuk semua jenis bakteri uji menunjukan hasil yang terbesar. Dua bakteri dengan diameter zona hambatan terbesar terdapat pada bakteri Enterobacter 10 dan Pseudomonas sp., masing-masing $14.93 \mathrm{~mm}$ dan $15.76 \mathrm{~mm}$. Kemudian ekstrak kasar akar Acanthus ilicifolius akan digunakan pada uji sensitivitas bakteri terhadap fraksi ekstrak.

Berdasarkan hasil KLT di atas diketahui bahwa perbandingan pelarut yang optimal memisahkan komponen-komponen adalah perbandingan antara etil asetat: $n$-hexane dengan perbandingan 2 : 1 yang menunjukkan jumlah noda paling banyak yaitu 5 noda dengan nilai $\mathrm{Rf}$ adalah 0.30 , $0.41, \quad 0.57, \quad 0.68$, dan 0.79 . Selanjutnya perbandingan pelarut tersebut digunakan sebagai pelarut dalam analisis Kromatografi Kolom Terbuka.

Hasil penelitian memperlihatkan bahwa jumlah noda tertinggi (3 noda) terdapat pada fraksi II dengan berat tertinggi yaitu $0,3863 \mathrm{~g}$ dan fraksi III dengan berat fraksi terkecil yaitu 0,1078 g. Fraksi-frraksi yang diperoleh dari Kromatografi Kolom Terbuka diuji kembali untuk mengetahui fraksi yang paling aktif terhadap bakteri uji. Fraksi meliputi perlakuan fraksi I-V dengan konsentrasi masing 5, 10. 20. 40 dan 80 ( $\mu \mathrm{g} /$ disk) dan kontrol $(80 \mu \mathrm{g} /$ disk) dalam waktu 24 jam, 48 jam dan 72 jam.

Hasil uji aktivitas fraksi-fraksi terhadap bakteri uji ditunjukkan pada Tabel. 1. Pada uji Kromatografi Kolom Terbuka (KKT) terhadap bakteri Klebsiella sp. Fraksi I-V menunjukkan bahwa nilai tertinggi terdapat pada fraksi III dengan konsentrasi $80 \mu \mathrm{g} /$ disk yaitu $13.22 \pm$ 0.50 dalam waktu 24 jam. Secara umum penambahan konsentrasi, yaitu 5, 10. 20. 40 dan 80 ( $\mu \mathrm{g} /$ disk) pada bakteri uji Klebsiella sp. memperlihatkan hasil bahwa tidak pengaruh terhadap besaran zona hambat. Hasil uji aktivitas fraksi I-V terhadap bakteri CNS ditunjukkan pada Tabel 2. Nilai tertinggi fraksi I-V terdapat pada fraksi I konsentrasi 20 $\mu \mathrm{g} /$ disk yaitu $11.70 \pm 0.36$ dalam waktu 72 jam dan fraksi II konsentrasi $40 \mu \mathrm{g} /$ disk yaitu 11.80 \pm 0.16 dalam waktu 24 jam. Diameter zona hambat dari masing-masing konsentrasi fraksi mengalami penurunan pada pengamatan 24 jam hingga 72 jam.

Uji aktivitas fraksi I-V terhadap bakteri Entero 5 ditunjukkan pada Tabel 3. Hasil tertinggi terdapat pada fraksi I dengan konsentrasi $20 \mu \mathrm{mg} /$ disk yaitu $10.02 \pm 0.34$ dalam waktu 24 jam. Pada masing-masing konsentrasi pada fraksi I-V terhadap Entero 5 mengalami penurunan besaran zona hambat pada pengamatan 24 jam, 48 jam, dan 72 jam. Hasil uji aktivitas fraksi I-V terhadap bakteri Entero 10 ditunjukkan pada Tabel 4. Besaran zona hambat tertinggi terdapat pada fraksi III dengan konsentrasi 5 $\mu \mathrm{g} /$ disk dalam pengamatan 24 jam yaitu $13.98 \pm 0.58$. Penambahan konsentrasi pada masing-masing fraksi tidak mempengaruhi besaran zona hambat. Besaran zona hambat dari 
Tabel 1. Aktivitas Antibakteri Fraksi I - V terhadap Klebsiella

\begin{tabular}{|c|c|c|c|c|c|c|c|c|c|c|}
\hline \multirow{2}{*}{ Fraksi } & \multirow{2}{*}{$\begin{array}{c}\text { Konsentrasi } \\
(\mu \mathrm{g} / \text { disk) }\end{array}$} & \multicolumn{9}{|c|}{ Diameter Zona Hambat (mm) } \\
\hline & & \multicolumn{3}{|c|}{24 jam } & \multicolumn{3}{|c|}{48 jam } & \multicolumn{3}{|c|}{72 jam } \\
\hline \multirow[t]{6}{*}{1} & 5 & 10.73 & \pm & 0.14 & 9.83 & \pm & 1.24 & 8.56 & \pm & 0.15 \\
\hline & 10 & 10.45 & \pm & 0.40 & 10.11 & \pm & 0.73 & 8.65 & \pm & 0.25 \\
\hline & 20 & 12.20 & \pm & 1.23 & 11.34 & \pm & 1.32 & 7.84 & \pm & 0.50 \\
\hline & 40 & 8.70 & \pm & 0.43 & 8.04 & \pm & 0.01 & 7.85 & \pm & 0.13 \\
\hline & 80 & 10.70 & \pm & 0.52 & 8.50 & \pm & 0.15 & 7.94 & \pm & 0.12 \\
\hline & $\mathrm{K}$ & 8.01 & \pm & 0.20 & 7.55 & \pm & 0.12 & 7.24 & \pm & 0.26 \\
\hline \multirow[t]{6}{*}{ ॥ } & 5 & 10.40 & \pm & 0.26 & 10.01 & \pm & 0.23 & 9.84 & \pm & 0.15 \\
\hline & 10 & 8.93 & \pm & 0.20 & 8.97 & \pm & 0.25 & 8.91 & \pm & 0.37 \\
\hline & 20 & 7.68 & \pm & 0.38 & 7.67 & \pm & 0.50 & 7.45 & \pm & 0.41 \\
\hline & 40 & 8.29 & \pm & 0.29 & 8.19 & \pm & 0.51 & 8.01 & \pm & 0.39 \\
\hline & 80 & 8.54 & \pm & 0.25 & 8.48 & \pm & 0.31 & 8.50 & \pm & 0.23 \\
\hline & $K$ & 7.01 & \pm & 0.23 & 6.90 & \pm & 0.27 & 6.76 & \pm & 0.19 \\
\hline \multirow[t]{6}{*}{ III } & 5 & 10.23 & \pm & 0.12 & 9.55 & \pm & 0.28 & 9.43 & \pm & 0.13 \\
\hline & 10 & 11.00 & \pm & 0.56 & 10.62 & \pm & 0.45 & 9.89 & \pm & 0.49 \\
\hline & 20 & 11.85 & \pm & 1.21 & 12.12 & \pm & 0.82 & 10.93 & \pm & 0.31 \\
\hline & 40 & 11.50 & \pm & 1.18 & 11.53 & \pm & 1.01 & 11.59 & \pm & 0.27 \\
\hline & 80 & 13.22 & \pm & 0.50 & 12.61 & \pm & 0.37 & 11.65 & \pm & 0.51 \\
\hline & K & 7.58 & \pm & 0.07 & 7.40 & \pm & 0.15 & 7.31 & \pm & 0.23 \\
\hline \multirow[t]{6}{*}{ IV } & 5 & 8.65 & \pm & 0.57 & 8.23 & \pm & 0.08 & 7.96 & \pm & 0.27 \\
\hline & 10 & 9.99 & \pm & 0.75 & 9.96 & \pm & 0.66 & 9.79 & \pm & 0.68 \\
\hline & 20 & 8.56 & \pm & 0.55 & 8.51 & \pm & 0.46 & 8.90 & \pm & 0.19 \\
\hline & 40 & 9.07 & \pm & 0.07 & 8.90 & \pm & 0.14 & 8.80 & \pm & 0.23 \\
\hline & 80 & 11.09 & \pm & 0.32 & 10.95 & \pm & 0.35 & 10.77 & \pm & 0.36 \\
\hline & K & 7.73 & \pm & 0.30 & 7.48 & \pm & 0.27 & 7.29 & \pm & 0.09 \\
\hline \multirow[t]{6}{*}{ V } & 5 & 12.73 & \pm & 0.44 & 12.19 & \pm & 0.19 & 12.08 & \pm & 0.17 \\
\hline & 10 & 10.33 & \pm & 0.76 & 10.26 & \pm & 0.58 & 9.61 & \pm & 0.24 \\
\hline & 20 & 12.89 & \pm & 0.16 & 11.81 & \pm & 0.26 & 12.28 & \pm & 0.29 \\
\hline & 40 & 10.65 & \pm & 0.80 & 11.46 & \pm & 0.25 & 11.07 & \pm & 0.85 \\
\hline & 80 & 12.36 & \pm & 0.23 & 12.05 & \pm & 0.22 & 11.13 & \pm & 0.30 \\
\hline & K & 7.77 & \pm & 0.10 & 7.36 & \pm & 0.21 & 7.36 & \pm & 0.32 \\
\hline
\end{tabular}

masing-masing konsentrasi fraksi I-V semakin menurun pada pengamatan 24 jam, 48 jam dan 72 jam.

Hasil uji aktivitas fraksi I-V terhadap bakteri E. Coli ditunjukkan pada Tabel 5. Nilai tertinggi terdapat pada fraksi II konsentrasi 20 $\mu \mathrm{g} /$ disk pada pengamatan 24 jam yaitu 13.07 \pm 1.59 dan fraksi III konsentrasi $5 \mu \mathrm{g} /$ disk pada pengamatan 24 jam yaitu $13.10 \pm 0.04$.

Hasil uji aktivitas fraksi I-V terhadap Pseudomonas sp. ditunjukkan pada Tabel 6. Nilai tertinggi terdapat pada fraksi III dengan konsentrasi $5 \mu \mathrm{g} /$ disk pada pengamatan 24 jam yaitu sebesar $13.15 \pm 1.15$. Masing-masing fraksi menunjukkan bahwa besaran zona hambat pada tiap konsentrasi mengalami penurunan pada pengamatan 24 jam, 48 jam dan 72 jam.

Uji kontrol positif dilakukan untuk melihat perbedaan aktivitas daya hambat kedua jenis antibiotik yaitu amoxicilin dan streptomicyn dalam menghambat bakteri patogen seperti Klebsiella, Eschericia coli, Pseudomonas sp., CNS, Entero 5 dan Entero 10. Hasil uji memperlihatkan bahwa pada antibiotik amoxicilin tidak terbentuk adanya zona hambat terhadap bakteri uji. Tidak terbentuknya zona hambat pada amoxicilin diduga disebabkan karena bakteri MDR yang diujikan memiliki resistensi intrinsik terhadap amoxicilin (Putri et al., 2014). Resistensi intrinsik dari bakteri terbentuk oleh enzim $\beta$-laktamase yang dapat menonaktifkan sifat antibiotik 
Tabel 2. Aktivitas antiBakteri Fraksi I - V terhadap Bakteri CNS

\begin{tabular}{|c|c|c|c|c|c|c|c|c|c|c|}
\hline \multirow{3}{*}{$\frac{\text { Fraksi }}{1}$} & \multirow{3}{*}{$\begin{array}{l}\text { konsentrasi } \\
(\mu \mathrm{g} / \text { disk) }\end{array}$} & \multicolumn{9}{|c|}{ Diameter Zona Hambat (mm) } \\
\hline & & \multicolumn{3}{|c|}{24 jam } & \multicolumn{3}{|c|}{48 jam } & \multicolumn{3}{|c|}{72 jam } \\
\hline & & 8.55 & \pm & 0.24 & 8.59 & \pm & 0.16 & 8.39 & \pm & 0.21 \\
\hline & 10 & 10.52 & \pm & 0.72 & 9.71 & \pm & 0.17 & 8.56 & \pm & 0.28 \\
\hline & 20 & 8.77 & \pm & 0.61 & 9.61 & \pm & 0.66 & 11.70 & \pm & 0.36 \\
\hline & 40 & 8.31 & \pm & 0.03 & 8.19 & \pm & 0.11 & 7.85 & \pm & 0.13 \\
\hline & 80 & 10.96 & \pm & 0.46 & 9.73 & \pm & 0.45 & 9.00 & \pm & 0.58 \\
\hline & $\mathrm{K}$ & 7.67 & \pm & 0.10 & 7.24 & \pm & 0.12 & 7.25 & \pm & 0.08 \\
\hline \multirow[t]{6}{*}{ II } & 5 & 9.93 & \pm & 0.02 & 9.43 & \pm & 0.29 & 9.36 & \pm & 0.23 \\
\hline & 10 & 10.76 & \pm & 0.30 & 10.67 & \pm & 0.47 & 10.13 & \pm & 0.36 \\
\hline & 20 & 10.13 & \pm & 0.97 & 9.92 & \pm & 0.98 & 9.44 & \pm & 0.37 \\
\hline & 40 & 11.80 & \pm & 0.16 & 11.14 & \pm & 0.43 & 10.89 & \pm & 0.65 \\
\hline & 80 & 8.73 & \pm & 0.34 & 8.73 & \pm & 0.22 & 8.19 & \pm & 0.14 \\
\hline & K & 7.66 & \pm & 0.24 & 7.64 & \pm & 0.25 & 7.42 & \pm & 0.10 \\
\hline \multirow[t]{6}{*}{ III } & 5 & 11.41 & \pm & 0.72 & 11.23 & \pm & 0.71 & 10.78 & \pm & 0.55 \\
\hline & 10 & 10.81 & \pm & 0.21 & 10.50 & \pm & 0.33 & 9.89 & \pm & 0.62 \\
\hline & 20 & 8.95 & \pm & 0.02 & 8.69 & \pm & 0.22 & 8.40 & \pm & 0.21 \\
\hline & 40 & 8.94 & \pm & 0.04 & 8.69 & \pm & 0.19 & 8.27 & \pm & 0.07 \\
\hline & 80 & 10.38 & \pm & 0.42 & 10.22 & \pm & 0.16 & 9.86 & \pm & 0.21 \\
\hline & K & 8.03 & \pm & 0.01 & 7.63 & \pm & 0.27 & 7.59 & \pm & 0.18 \\
\hline \multirow[t]{6}{*}{ IV } & 5 & 11.12 & \pm & 0.45 & 9.81 & \pm & 0.51 & 10.07 & \pm & 0.26 \\
\hline & 10 & 11.41 & \pm & 1.55 & 11.05 & \pm & 1.33 & 10.61 & \pm & 1.20 \\
\hline & 20 & 8.54 & \pm & 0.39 & 8.31 & \pm & 0.32 & 8.36 & \pm & 0.32 \\
\hline & 40 & 8.06 & \pm & 0.05 & 8.07 & \pm & 0.06 & 7.99 & \pm & 0.14 \\
\hline & 80 & 10.47 & \pm & 0.02 & 10.26 & \pm & 0.05 & 9.90 & \pm & 0.06 \\
\hline & $K$ & 7.63 & \pm & 0.09 & 7.18 & \pm & 0.15 & 7.14 & \pm & 0.14 \\
\hline \multirow[t]{6}{*}{ V } & 5 & 9.45 & \pm & 0.26 & 9.41 & \pm & 0.27 & 9.12 & \pm & 0.03 \\
\hline & 10 & 9.19 & \pm & 0.29 & 8.95 & \pm & 0.46 & 8.80 & \pm & 0.51 \\
\hline & 20 & 10.32 & \pm & 0.64 & 10.09 & \pm & 0.14 & 9.64 & \pm & 0.39 \\
\hline & 40 & 11.21 & \pm & 0.75 & 10.79 & \pm & 0.57 & 10.53 & \pm & 0.48 \\
\hline & 80 & 8.45 & \pm & 0.17 & 8.45 & \pm & 0.17 & 8.17 & \pm & 0.14 \\
\hline & $K$ & 7.66 & \pm & 0.21 & 7.59 & \pm & 0.23 & 7.16 & \pm & 0.09 \\
\hline
\end{tabular}

dari amoxicilin (Wibowo, 2015). Menurut Gilman (2012), amoxicilin dinilai kurang efektif dikarenakan mudah terhidrolisis oleh enzim $\beta$ laktamase sehingga diperlukan senyawa lain seperti asam klavulanat yang berperan sebagai inhibitor enzim $\beta$-laktamase sehingga amoxicilin dapat bekerja secara optimal. Hasil uji dengan menggunakan antibiotik streptomycin terhadap bakteri uji memperlihatkan adanya zona hambat yang terbentuk. Adanya zona hambat ini menunjukkan bahwa bakteri uji diduga belum resisten terhadap streptomycin. Aktivitas antibakteri pada streptomycin lebih baik dibandingkan dengan amoxicilin (Adedayo et al., 2016). Perlakuan uji aktivitas antibakteri juga dilakukan pada kontrol negatif yaitu n-heksan, etil asetat dan metanol. Uji kontrol negatif bertujuan untuk mengetahui cemaran yang ada pada media tumbuh bakteri. Pada uji kontrol negatif tidak terbentuk adanya zona hambat sehingga hal ini dapat menjelaskan bahwa aktivitas antibakteri dari masing-masing ekstrak tidak dipengaruhi oleh pelarut yang digunakan melainkan disebabkan oleh adanya senyawa aktif yang terkandung pada ekstrak (Opa et al., 2018).

Dugaan adanya potensi antibakteri pada ekstrak Acanthus ilisifolius dibuktikan dengan uji aktivitas antibakteri terhadap bakteri uji. Adanya aktivitas antibakteri ditunjukkan dengan terbentuknya zona hambat disekitar paper disk. Hasil pengamatan memperlihatkan bahwa pada masing-masing ekstrak dengan fraksi etil asetat memiliki aktivitas antibakteri yang 
Tabel 3. Aktivitas antiBakteri Fraksi I - V terhadap Bakteri Entero 5

\begin{tabular}{|c|c|c|c|c|c|c|c|c|c|c|}
\hline \multirow{3}{*}{$\begin{array}{c}\text { Fraksi } \\
\mathrm{I}\end{array}$} & \multirow{3}{*}{$\begin{array}{c}\text { konsentrasi } \\
(\mu \mathrm{g} / \text { disk })\end{array}$} & \multicolumn{9}{|c|}{ Diameter Zona Hambat (mm) } \\
\hline & & \multicolumn{3}{|c|}{24 jam } & \multicolumn{3}{|c|}{$48 \mathrm{jam}$} & \multicolumn{3}{|c|}{72 jam } \\
\hline & & 9.46 & \pm & 0.35 & 9.23 & \pm & 0.29 & 9.11 & \pm & 0.27 \\
\hline & 10 & 9.88 & \pm & 0.17 & 9.64 & \pm & 0.23 & 9.17 & \pm & 0.11 \\
\hline & 20 & 10.02 & \pm & 0.34 & 9.70 & \pm & 0.56 & 9.57 & \pm & 0.58 \\
\hline & 40 & 9.45 & \pm & 0.31 & 9.02 & \pm & 0.23 & 8.57 & \pm & 0.39 \\
\hline & 80 & 9.94 & \pm & 0.03 & 9.54 & \pm & 0.30 & 9.38 & \pm & 0.09 \\
\hline & $\mathrm{K}$ & 7.68 & \pm & 0.16 & 7.33 & \pm & 0.13 & 7.17 & \pm & 0.06 \\
\hline \multirow[t]{6}{*}{ II } & 5 & 8.69 & \pm & 0.38 & 8.42 & \pm & 0.24 & 8.35 & \pm & 0.33 \\
\hline & 10 & 8.28 & \pm & 0.25 & 7.63 & \pm & 0.18 & 7.63 & \pm & 0.28 \\
\hline & 20 & 8.99 & \pm & 0.92 & 8.51 & \pm & 0.34 & 8.31 & \pm & 0.10 \\
\hline & 40 & 8.78 & \pm & 0.52 & 9.24 & \pm & 0.12 & 8.38 & \pm & 0.33 \\
\hline & 80 & 7.99 & \pm & 0.22 & 7.73 & \pm & 0.38 & 7.27 & \pm & 0.05 \\
\hline & $K$ & 7.51 & \pm & 0.37 & 7.10 & \pm & 0.23 & 6.81 & \pm & 0.08 \\
\hline \multirow[t]{6}{*}{ III } & 5 & 8.35 & \pm & 0.15 & 8.23 & \pm & 0.11 & 8.24 & \pm & 0.04 \\
\hline & 10 & 9.17 & \pm & 0.40 & 8.78 & \pm & 0.47 & 8.38 & \pm & 0.25 \\
\hline & 20 & 8.63 & \pm & 0.17 & 8.22 & \pm & 0.03 & 8.39 & \pm & 0.12 \\
\hline & 40 & 8.44 & \pm & 0.19 & 8.42 & \pm & 0.17 & 7.67 & \pm & 0.29 \\
\hline & 80 & 8.67 & \pm & 0.16 & 8.14 & \pm & 0.27 & 7.86 & \pm & 0.13 \\
\hline & K & 7.68 & \pm & 0.35 & 7.27 & \pm & 0.13 & 7.19 & \pm & 0.12 \\
\hline \multirow[t]{6}{*}{ IV } & 5 & 9.64 & \pm & 0.91 & 9.71 & \pm & 0.77 & 9.49 & \pm & 0.51 \\
\hline & 10 & 9.13 & \pm & 0.54 & 9.42 & \pm & 0.17 & 8.92 & \pm & 0.24 \\
\hline & 20 & 8.48 & \pm & 0.01 & 7.93 & \pm & 0.09 & 7.52 & \pm & 0.28 \\
\hline & 40 & 8.85 & \pm & 0.18 & 8.69 & \pm & 0.29 & 8.37 & \pm & 0.53 \\
\hline & 80 & 9.14 & \pm & 0.83 & 8.29 & \pm & 0.71 & 7.51 & \pm & 0.30 \\
\hline & K & 7.70 & \pm & 0.22 & 6.97 & \pm & 0.12 & 6.55 & \pm & 0.20 \\
\hline \multirow[t]{6}{*}{ V } & 5 & 8.56 & \pm & 0.15 & 8.60 & \pm & 0.12 & 7.72 & \pm & 0.32 \\
\hline & 10 & 8.65 & \pm & 0.25 & 8.42 & \pm & 0.13 & 7.53 & \pm & 0.27 \\
\hline & 20 & 7.84 & \pm & 0.50 & 7.48 & \pm & 0.37 & 7.15 & \pm & 0.05 \\
\hline & 40 & 7.85 & \pm & 0.13 & 7.37 & \pm & 0.17 & 7.22 & \pm & 0.20 \\
\hline & 80 & 7.94 & \pm & 0.12 & 7.41 & \pm & 0.15 & 7.34 & \pm & 0.16 \\
\hline & K & 7.34 & \pm & 0.20 & 6.73 & \pm & 0.33 & 6.49 & \pm & 0.25 \\
\hline
\end{tabular}

tinggi terhadap Klebsiella yaitu pada ekstrak daun sebesar $11.13 \mathrm{~mm}$, ekstrak batang sebesar $11.45 \mathrm{~mm}$ dan ekstrak akar sebesar $14.91 \mathrm{~mm}$. Pada ekstrak metanol dihasilkan zona hambat tertinggi terhadap bakteri Entero 5 pada ekstrak daun dan batang yaitu sebesar $12.89 \mathrm{~mm}$ dan $10.47 \mathrm{~mm}$ sedangkan pada ekstrak akar memiliki zona hambat terbesar terhadap bakteri Escherichia coli yaitu sebesar $11.80 \mathrm{~mm}$. Fraksi $\mathrm{n}$-heksan tidak menunjukkan adanya daya hambat atau aktivitas antibakteri dikarenakan tidak terbentuknya diameter zona hambat. Perbandingan daya hambat etil asetat lebih baik bila dibandingkan dengan ekstrak metanol. Secara umum, fraksi etil asetat pada ekstrak Acanthus ilisifolius memiliki diameter zona hambat yang luas serta mempunyai reaksi daya hambat yang termasuk cepat (Septiani et al., 2013).

Ekstrak kasar akar Acanthus ilisifosius dilakukan uji sensitivitas terhadap fraksi ekstrak. Penentuan eluen dilakukan dengan KLT dan didapatkan 5 noda (spot) dari perbandingan etil asetat : $n$-heksan yaitu 2 : 1. Jumlah noda yang didapat memiliki nilai Rf sebesar $0.30,0.41,0.57,0.68$, dan 0.79. Fraksi ekstrak yang diperoleh dari kromatografi kolom terbuka dilakukan uji aktivitas antibakteri terhadap bakteri uji. Penambahan konsentrasi pada masing-masing ekstrak terhadap bakteri uji tidak mempengaruhi hasil besaran zona hambat. Hasil uji memperlihatkan aktivitas antibakteri paling tinggi terjadi pada pengamatan 24 jam 
Tabel 4. Aktivitas antiBakteri Fraksi I - V terhadap Bakteri Entero 10

\begin{tabular}{|c|c|c|c|c|c|c|c|c|c|c|}
\hline \multirow{3}{*}{$\begin{array}{c}\text { Fraksi } \\
\mathrm{I}\end{array}$} & \multirow{3}{*}{ 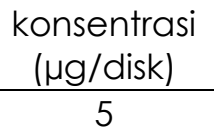 } & \multicolumn{9}{|c|}{ Diameter Zona Hambat (mm) } \\
\hline & & \multicolumn{3}{|c|}{24 jam } & \multicolumn{3}{|c|}{$48 \mathrm{jam}$} & \multicolumn{3}{|c|}{72 jam } \\
\hline & & 9.38 & \pm & 0.27 & 9.33 & \pm & 0.17 & 8.55 & \pm & 0.33 \\
\hline & 10 & 8.48 & \pm & 0.37 & 8.28 & \pm & 0.24 & 7.34 & \pm & 0.29 \\
\hline & 20 & 10.07 & \pm & 0.18 & 8.93 & \pm & 0.20 & 8.10 & \pm & 0.58 \\
\hline & 40 & 9.93 & \pm & 1.00 & 10.39 & \pm & 0.02 & 9.54 & \pm & 0.20 \\
\hline & 80 & 8.67 & \pm & 0.16 & 8.45 & \pm & 0.28 & 7.92 & \pm & 0.36 \\
\hline & $\mathrm{K}$ & 7.30 & \pm & 0.09 & 6.88 & \pm & 0.10 & 6.74 & \pm & 0.15 \\
\hline \multirow[t]{6}{*}{ ॥ } & 5 & 12.82 & \pm & 0.55 & 11.95 & \pm & 0.79 & 11.13 & \pm & 0.62 \\
\hline & 10 & 11.18 & \pm & 0.43 & 10.41 & \pm & 0.11 & 9.68 & \pm & 0.04 \\
\hline & 20 & 9.58 & \pm & 0.61 & 8.96 & \pm & 0.47 & 8.55 & \pm & 0.22 \\
\hline & 40 & 9.53 & \pm & 0.06 & 9.12 & \pm & 0.25 & 8.51 & \pm & 0.14 \\
\hline & 80 & 10.15 & \pm & 0.06 & 9.45 & \pm & 0.24 & 8.73 & \pm & 0.22 \\
\hline & $K$ & 6.93 & \pm & 0.26 & 6.53 & \pm & 0.26 & 6.25 & \pm & 0.05 \\
\hline \multirow[t]{6}{*}{ III } & 5 & 13.98 & \pm & 0.58 & 13.11 & \pm & 0.24 & 11.85 & \pm & 0.63 \\
\hline & 10 & 11.09 & \pm & 0.51 & 10.09 & \pm & 0.36 & 9.02 & \pm & 0.18 \\
\hline & 20 & 12.13 & \pm & 0.19 & 10.77 & \pm & 0.50 & 9.96 & \pm & 0.81 \\
\hline & 40 & 13.60 & \pm & 0.42 & 12.98 & \pm & 0.80 & 11.29 & \pm & 0.29 \\
\hline & 80 & 8.05 & \pm & 0.70 & 7.45 & \pm & 0.33 & 6.80 & \pm & 0.08 \\
\hline & $K$ & 7.05 & \pm & 0.19 & 7.14 & \pm & 0.06 & 6.42 & \pm & 0.29 \\
\hline \multirow[t]{6}{*}{ IV } & 5 & 10.55 & \pm & 0.40 & 9.60 & \pm & 0.34 & 8.76 & \pm & 0.43 \\
\hline & 10 & 10.02 & \pm & 0.29 & 9.69 & \pm & 0.27 & 8.71 & \pm & 0.32 \\
\hline & 20 & 13.15 & \pm & 1.15 & 11.55 & \pm & 0.23 & 10.65 & \pm & 0.38 \\
\hline & 40 & 10.83 & \pm & 0.55 & 10.57 & \pm & 0.26 & 9.42 & \pm & 0.20 \\
\hline & 80 & 10.93 & \pm & 1.00 & 10.88 & \pm & 0.83 & 9.60 & \pm & 0.22 \\
\hline & $\mathrm{K}$ & 6.89 & \pm & 0.32 & 6.56 & \pm & 0.55 & 6.42 & \pm & 0.41 \\
\hline \multirow[t]{6}{*}{$\mathrm{V}$} & 5 & 11.42 & \pm & 0.09 & 10.94 & \pm & 0.26 & 10.50 & \pm & 0.51 \\
\hline & 10 & 10.06 & \pm & 0.62 & 8.94 & \pm & 0.18 & 8.50 & \pm & 0.38 \\
\hline & 20 & 8.79 & \pm & 0.83 & 7.96 & \pm & 0.19 & 7.74 & \pm & 0.16 \\
\hline & 40 & 7.97 & \pm & 0.54 & 7.60 & \pm & 0.24 & 7.16 & \pm & 0.18 \\
\hline & 80 & 8.17 & \pm & 0.07 & 7.87 & \pm & 0.03 & 7.58 & \pm & 0.17 \\
\hline & $K$ & 6.99 & \pm & 0.21 & 6.93 & \pm & 0.05 & 6.67 & \pm & 0.11 \\
\hline
\end{tabular}

Tabel 5. Aktivitas antiBakteri Fraksi I - V terhadap Bakteri E.coli

\begin{tabular}{|c|c|c|c|c|c|c|c|c|c|c|}
\hline \multirow{2}{*}{ Fraksi } & \multirow{2}{*}{$\begin{array}{c}\text { konsentrasi } \\
(\mu \mathrm{g} / \text { disk) }\end{array}$} & \multicolumn{9}{|c|}{ Diameter Zona Hambat (mm) } \\
\hline & & \multicolumn{3}{|c|}{$24 \mathrm{jam}$} & \multicolumn{3}{|c|}{$48 \mathrm{jam}$} & \multicolumn{3}{|c|}{72 jam } \\
\hline \multirow[t]{6}{*}{ I } & 5 & 9.80 & \pm & 0.26 & 9.45 & \pm & 0.33 & 9.34 & \pm & 0.29 \\
\hline & 10 & 12.18 & \pm & 0.26 & 11.82 & \pm & 0.42 & 11.51 & \pm & 0.39 \\
\hline & 20 & 12.01 & \pm & 0.87 & 11.48 & \pm & 0.61 & 10.30 & \pm & 0.56 \\
\hline & 40 & 12.62 & \pm & 0.70 & 10.90 & \pm & 0.74 & 9.59 & \pm & 0.07 \\
\hline & 80 & 11.65 & \pm & 0.58 & 11.01 & \pm & 0.30 & 9.79 & \pm & 0.13 \\
\hline & $\mathrm{K}$ & 7.59 & \pm & 0.12 & 7.25 & \pm & 0.18 & 6.73 & \pm & 0.35 \\
\hline \multirow[t]{6}{*}{ II } & 5 & 13.06 & \pm & 0.24 & 11.93 & \pm & 0.52 & 10.88 & \pm & 0.30 \\
\hline & 10 & 11.09 & \pm & 0.49 & 9.09 & \pm & 0.49 & 7.95 & \pm & 0.02 \\
\hline & 20 & 13.07 & \pm & 1.59 & 10.45 & \pm & 0.14 & 9.25 & \pm & 0.28 \\
\hline & 40 & 12.18 & \pm & 0.57 & 11.74 & \pm & 0.02 & 10.25 & \pm & 0.46 \\
\hline & 80 & 10.91 & \pm & 0.49 & 8.59 & \pm & 0.27 & 7.94 & \pm & 0.04 \\
\hline & K & 7.72 & \pm & 0.17 & 7.26 & \pm & 0.09 & 7.26 & \pm & 0.09 \\
\hline
\end{tabular}


Tabel 5. Aktivitas antiBakteri Fraksi I - V terhadap Bakteri E.coli (lanjutan)

\begin{tabular}{|c|c|c|c|c|c|c|c|c|c|c|}
\hline \multirow{3}{*}{$\begin{array}{c}\text { Fraksi } \\
\text { III }\end{array}$} & \multirow{3}{*}{$\begin{array}{c}\text { konsentrasi } \\
\text { ( } \mathrm{gg} / \text { disk) }\end{array}$} & \multicolumn{9}{|c|}{ Diameter Zona Hambat (mm) } \\
\hline & & \multicolumn{3}{|c|}{24 jam } & \multicolumn{3}{|c|}{48 jam } & \multicolumn{3}{|c|}{$72 \mathrm{jam}$} \\
\hline & & 13.10 & \pm & 0.04 & 12.64 & \pm & 0.17 & 11.30 & \pm & 0.15 \\
\hline & 10 & 11.19 & \pm & 0.34 & 9.45 & \pm & 0.31 & 8.45 & \pm & 0.17 \\
\hline & 20 & 10.37 & \pm & 0.27 & 9.94 & \pm & 0.03 & 8.87 & \pm & 0.38 \\
\hline & 40 & 11.40 & \pm & 0.12 & 9.68 & \pm & 0.16 & 8.44 & \pm & 0.31 \\
\hline & 80 & 11.13 & \pm & 0.44 & 10.00 & \pm & 0.60 & 9.30 & \pm & 0.08 \\
\hline & K & 7.09 & \pm & 0.22 & 6.98 & \pm & 0.57 & 6.50 & \pm & 0.28 \\
\hline \multirow[t]{6}{*}{ IV } & 5 & 8.91 & \pm & 0.28 & 10.94 & \pm & 0.35 & 9.61 & \pm & 1.01 \\
\hline & 10 & 8.87 & \pm & 0.60 & 8.58 & \pm & 0.36 & 6.93 & \pm & 0.80 \\
\hline & 20 & 12.54 & \pm & 0.90 & 12.21 & \pm & 0.08 & 11.87 & \pm & 0.62 \\
\hline & 40 & 10.94 & \pm & 0.30 & 10.61 & \pm & 0.58 & 10.39 & \pm & 0.59 \\
\hline & 80 & 10.12 & \pm & 0.29 & 9.71 & \pm & 0.53 & 9.02 & \pm & 0.31 \\
\hline & K & 7.40 & \pm & 0.05 & 7.19 & \pm & 0.04 & 7.00 & \pm & 0.20 \\
\hline \multirow[t]{6}{*}{$\mathrm{V}$} & 5 & 11.60 & \pm & 0.17 & 10.56 & \pm & 0.55 & 9.87 & \pm & 0.40 \\
\hline & 10 & 8.70 & \pm & 0.60 & 8.50 & \pm & 0.53 & 8.32 & \pm & 0.13 \\
\hline & 20 & 9.30 & \pm & 0.64 & 8.66 & \pm & 0.80 & 8.01 & \pm & 0.76 \\
\hline & 40 & 10.62 & \pm & 0.25 & 9.18 & \pm & 0.17 & 8.82 & \pm & 0.14 \\
\hline & 80 & 9.79 & \pm & 0.54 & 9.29 & \pm & 0.91 & 9.25 & \pm & 0.12 \\
\hline & K & 7.07 & \pm & 0.25 & 6.94 & \pm & 0.27 & 6.66 & \pm & 0.10 \\
\hline
\end{tabular}

Tabel 6. Aktivitas antiBakteri Fraksi I-V terhadap Bakteri Pseudomonas sp.

\begin{tabular}{|c|c|c|c|c|c|c|c|c|c|c|}
\hline \multirow{3}{*}{$\begin{array}{c}\text { Fraksi } \\
\end{array}$} & \multirow{3}{*}{$\begin{array}{c}\text { konsentrasi } \\
\text { ( } \mu \mathrm{g} / \text { disk) }\end{array}$} & \multicolumn{9}{|c|}{ Diameter Zona Hambat (mm) } \\
\hline & & \multicolumn{3}{|c|}{24 jam } & \multicolumn{3}{|c|}{48 jam } & \multicolumn{3}{|c|}{72 jam } \\
\hline & & 8.55 & \pm & 0.01 & 8.20 & \pm & 0.01 & 7.75 & \pm & 0.05 \\
\hline & 10 & 9.25 & \pm & 0.05 & 8.79 & \pm & 0.01 & 8.22 & \pm & 0.02 \\
\hline & 20 & 9.68 & \pm & 0.16 & 9.09 & \pm & 0.09 & 8.05 & \pm & 0.26 \\
\hline & 40 & 9.07 & \pm & 0.09 & 8.78 & \pm & 0.21 & 7.82 & \pm & 0.32 \\
\hline & 80 & 7.82 & \pm & 0.32 & 7.45 & \pm & 0.09 & 7.45 & \pm & 0.09 \\
\hline & K & 7.47 & \pm & 0.17 & 6.72 & \pm & 0.24 & 6.66 & \pm & 0.20 \\
\hline \multirow[t]{6}{*}{ II } & 5 & 9.77 & \pm & 0.10 & 9.67 & \pm & 0.09 & 8.48 & \pm & 0.06 \\
\hline & 10 & 10.16 & \pm & 0.32 & 9.81 & \pm & 0.27 & 9.57 & \pm & 0.46 \\
\hline & 20 & 11.63 & \pm & 0.26 & 10.69 & \pm & 0.13 & 9.37 & \pm & 0.18 \\
\hline & 40 & 8.92 & \pm & 0.59 & 8.70 & \pm & 0.27 & 7.83 & \pm & 0.12 \\
\hline & 80 & 10.36 & \pm & 1.17 & 9.96 & \pm & 0.66 & 9.22 & \pm & 0.58 \\
\hline & $K$ & 7.63 & \pm & 0.28 & 7.26 & \pm & 0.19 & 6.53 & \pm & 0.28 \\
\hline \multirow[t]{6}{*}{ III } & 5 & 13.15 & \pm & 1.15 & 12.62 & \pm & 0.62 & 10.53 & \pm & 0.18 \\
\hline & 10 & 10.83 & \pm & 0.55 & 9.51 & \pm & 0.16 & 8.27 & \pm & 0.07 \\
\hline & 20 & 8.15 & \pm & 0.04 & 7.91 & \pm & 0.02 & 7.15 & \pm & 0.03 \\
\hline & 40 & 9.12 & \pm & 0.37 & 7.94 & \pm & 0.04 & 6.74 & \pm & 0.14 \\
\hline & 80 & 7.81 & \pm & 0.06 & 7.15 & \pm & 0.10 & 6.86 & \pm & 0.18 \\
\hline & K & 6.10 & \pm & 0.13 & 5.99 & \pm & 0.10 & 5.96 & \pm & 0.06 \\
\hline \multirow[t]{6}{*}{ IV } & 5 & 8.31 & \pm & 0.23 & 7.61 & \pm & 0.07 & 7.12 & \pm & 0.09 \\
\hline & 10 & 7.28 & \pm & 0.04 & 7.44 & \pm & 0.09 & 6.75 & \pm & 0.08 \\
\hline & 20 & 8.78 & \pm & 0.04 & 8.19 & \pm & 0.11 & 7.84 & \pm & 0.04 \\
\hline & 40 & 9.81 & \pm & 0.01 & 8.78 & \pm & 0.03 & 7.26 & \pm & 0.04 \\
\hline & 80 & 11.30 & \pm & 0.01 & 10.66 & \pm & 0.02 & 8.97 & \pm & 0.10 \\
\hline & K & 7.60 & \pm & 0.11 & 6.48 & \pm & 0.09 & 5.86 & \pm & 0.09 \\
\hline \multirow[t]{6}{*}{$\mathrm{V}$} & 5 & 8.30 & \pm & 0.05 & 8.14 & \pm & 0.11 & 7.47 & \pm & 0.04 \\
\hline & 10 & 8.32 & \pm & 0.34 & 8.02 & \pm & 0.16 & 7.35 & \pm & 0.05 \\
\hline & 20 & 7.97 & \pm & 0.12 & 7.08 & \pm & 0.09 & 6.93 & \pm & 0.09 \\
\hline & 40 & 7.04 & \pm & 0.09 & 6.86 & \pm & 0.10 & 5.97 & \pm & 0.16 \\
\hline & 80 & 11.24 & \pm & 0.01 & 10.21 & \pm & 0.07 & 8.68 & \pm & 0.07 \\
\hline & $K$ & 6.15 & \pm & 0.08 & 6.12 & \pm & 0.10 & 6.11 & \pm & 0.10 \\
\hline
\end{tabular}


sedangakan pada pengamatan 48 jam dan 72 jam menunjukkan diameter zona hambat yang menurun. Hal ini membuktikan bahwa ekstrak jeruju memiliki sifat bakteriostatik. Menurut Purnamaningsih et al. (2017), aktivitas bakteriostatik ditandai dengan zona hambat yang terlihat keruh karena masih terdapat titik-titik bakteri. Hasil dari uji aktivitas antibakteri menunjukkan daya hambat bakteri dipengaruhi struktur dari dinding sel bakteri gram positif dan gram negatif. Struktur dinding sel gram positif lebih sederhana sehingga senyawa antibakteri lebih mudah masuk ke dalam sel dibandingkan dengan gram negatif yang memiliki struktur dinding sel yang lebih kompleks (Opa et al., 2018).

\section{KESIMPULAN}

Bahwa ekstrak akar, batang, daun jeruju Acanthus ilisifolius memiliki aktivitas antibakteri terhadap Klebsiella, CN, Escherichia coli, Entero 5, Entero 10 dan Pseudomonas sp. Aktifitas tertinggi ditunjukan oleh fraksi III ekstrak akar yaitu terhadap Enterobacter 10, Klebsiella sp., Pseudomonas sp. dan E. coli

\section{DAFTAR PUSTAKA.}

Adedayo, O., Olajuyigbe, O.O. \& AdeoyeIsijola, M.O. 2016. Synergistic Potential of Benzylpenicillin, Amoxicilin, and Streptomycin Antibiotics Againstts Selected Bacterial Species. Life Sci. J., 13(8):37-44.

Brock, T.D. \& Madigan, M.T. 1991. Biology of Microorganism $6^{\text {th }}$ Ed. Prentice-Hall International Inc., New Jersey.

Burgess, J., Hihi, A.K., Benard, C.Y., Branicky, R. \& Hekimi, S. 2003. Molecular Mechanism of Material Rescue in the clk-1 Mutants of Caenorhabditis elegans. J. Biol. Chem., 278(49):49555-49562.

Filius, M.P.G., Gyssens, I.C., Kershof, I.M., Roovers, P.J.E., Ott, A., Vulto, A.G., Verbrugh, H.A. \& Endtz, H.P. 2005. Colonization and Resistance Dynamics of Gram-Negative Bacteria in Patients during and after Hospitalization. Antimicrob. Agents Chemother. 49(7):2879-2886. doi: 10.1128/AAC.49.7.2 879-2886.2005
Gandjar, I.G. \& Rohman, A. 2007. Kimia Farmasi Analisis. Pustaka Pelajar, Yogyakarta, $419 \mathrm{hlm}$.

Gilman, A.G. 2012. Dasar Farmakologi Terapi Ed 10. EGC, Jakarta.

Harborne, J.B. 1987. Metode Fitokimia Penuntun Cara Modern Menganalisis Tumbuhan. Institut Teknologi Bandung, Bandung.

Kristanti, A.N., Aminah, N.S., Tanjung, M. \& Kurniadi, B. 2008. BukU Ajar Fitokimia. Airlangga University Press, Surabaya.

Manilal, A., Sujith, I.S., Kiran, G.S., Selvin, J. \& Shakir, C. 2009. Biopotentials of mangroves collected from the Southwest Coast of India. Glo. J. Biotechnol. 4(1):5965.

Noor, R.Y., Khazali, M. \& Suryadiputra, I.N.N. 1999. Paduan Pengenalan Mangrove di Indonesia. PKA/WI-IP, Bogor, $228 \mathrm{hlm}$.

Opa, S.L., Bara, R.A., Gerung, G.S., Rompas, R.M., Lintang, R.A.J. \& Sumilat, D.A. 2018. Uji Aktivitas Antibateri Fraksi N-Heksana, Metanol dan Air dari Ascidian Lissoclinum sp. J. Pesisir Laut Trop. 1 (1):69-80.

Pavia, D.L., Lampman, G.M., Kriz, G.S. \& Engel, R.G. 1995. Introduction to Organic Laboratory Techniques : A Microscale Approach, 2nd Edition. Harcount Brace \& Company, Florida.

Purnamaningsih, N.A., Kalor, H. \& Atun, S. 2017. Uji Aktivitas Antibakteri Ekstrrak Temulawak (Curcuma xanthorrhiza) Terhadap Bakteri Escherichia coli ATTC 11229 dan Staphylococcus aureus ATCC 25923. J. Penelit. Saintek., 22(2):140-147.

Putri, A.A., Rasyid, R. \& Rahmatini. 2014. Perbedaan Sensitivitas Kuman Pseudomonas aeruginosa Penyebab Nosokomial Terhadap Beberapa Antibiotika Generik dan Paten. J. Kesehatan Andalas., 3(3):327-331.

Septiani, G., S. B. Prayitno dan S. Anggoro. 2013. Potensi Antibakteri Ekstrak Daun Jeruju (Acabthus ilicifolius) terhadap Vibrio harveyi secara In Vitro. J. Kedokteran Hewan., 7(1):17-20.

Siegel, J.D., Rhinehart, E., Jackson, M. Chiarello, L. \& The Healthcare Infection Control Practices Advisory Commite. 2007. Management of Multidrug-Resistant Organism in Health Care Setting. Am. J. Infection Control., 35(10):S165-S193. 
Stahl, E. 1985. Analisis Obat Secara Kromatografi dan Mikroskopi. Institut Teknologi Bandung, Bandung.

Subagiyo, Setyati, W.A. \& Ridlo, A. 2005. Uji Bioaktivitas Ekstrak Batang Tumbuhan Benalu Mangrove (Cassytha filiformis) : II. Uji Anti Bakteri. Indo. J. Mar. Sci. 10(1):3540.
Volk \& Wheeler. 1990. Mikrobiologi Dasar Edisi Kelima Jilid Dua. Erlangga, Jakarta.

Wibowo, J.T. 2015. Resistensi Bakteri Patogen dan Strategi Mengatasi Bakteri Resisten. Oseana. 9(3):11-17. 